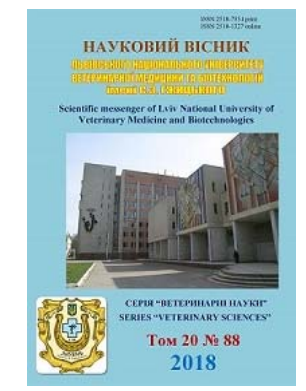

\author{
Науковий вісник Дьвівського національного університету \\ ветеринарної медицини та біотехнологій імені С.З. Гжицького
}

\author{
Scientific Messenger of Lviv National University \\ of Veterinary Medicine and Biotechnologies
}

\title{
Microscopic changes in the colon of puppies at experimental infection with parvovirus isolator cultivated in heterologous cell culture
}

\author{
N. Radsikhovskii \\ Zhytomyr National Agroecological University, Zhytomyr, Ukraine
}

Article info

Received 23.08.2018

Received in revised form 18.09.2018

Accepted 19.09.2018

Zhytomyr National Agroecological University, Staryi Blvd, 7. Zhytomyr, 10008. Ukraine.

Tel.: +38-067-725-65-07

E-mail:nickvet@ukr.net
Radsikhovskii, N. (2018). Microscopic changes in the colon of puppies at experimental infection with parvovirus isolator cultivated in heterologous cell culture. Scientific Messenger of Lviv National University of Veterinary Medicine and Biotechnologies, 20(88), 98-101. doi: $10.32718 /$ nvlvet8818

The article presents the results of the study of histological changes in the cecum, and colon of dogs for experimental infection with parvovirus enteritis. The histological examination of the small intestine, selected from corpses $(n=5)$ of puppies, dental labradorus with unborn, was infected with field isolator of parvovirus cultured on heterologous cell cultures (kidney kidney hamster (BHK-21), rabbit kidney (RK-13) and the renal mumps (SPEV). The presence of parvovirus, without any other association in experimental animals, is confirmed by the ELISA method and the solid-phase ELISA system. The purpose of this work was to study and characterize the microscopic changes in the colon for experimental contamination of dogs by parvovirus enteritis. The work was carried out at the Faculty of Veterinary Medicine of Zhytomyr National Agroecological University (ZNAEU). Anatomy of the animals was carried out in the special laboratory of the Department of Anatomy and Histology. The material of the study was pathological material taken during the pathoanatomical dissect of the puppies $(n=5)$, after experimental infection and euthanasia. The section of the cecum and the colon, were investigated. The main method used in the work was a histological study, and a description of the microstructural changes in the tissues of the organs. Histological studies of the bladder and intestine showed that microscopic changes in their walls were segmental. Some parts had well preserved the spots. Only moderate uneven swelling of the submucosal base, an increase in its blood vessels, and edema and partial lysis of collagen fibers are registered. In other areas, destruction was recorded. In some cases, only the upper part of the crypt disappeared. The cript stroma was disorganized and suppressed, while in the nuclei of a sufficiently large number of epithelial cells in the upper crypts, eosinophilic inclusions were recorded. In the large intestine, puppies for experimental infection with parvovirus isolate, cultured in the heterologous culture of the lesions, are localized in the cecum and the colon and have a segmental nature: in some areas the crypts is well preserved, while in others the destruction of the crypts is recorded. Local reaction of the system of specific immunity is characterized by hypertrophy of isolated and congested lymphoid nodes. There are small cells of lymphocyte necrosis. In the nuclei of the epithelial cytoplasm, as well as in the nuclei of the lymphocytes, eosinophilic inclusions of the corpuscles are detected.

Key words: canine parvoviridae, histological changes,_autopsy,_thick intestine, cecum, colon.

\section{Мікроскопічні зміни в товстій кишці цуценят за експериментального зараження ізолятом парвовіруса, культивованим у гетерологічній культурі клітин}

\section{М. Радзиховський}

Житомирський національний агроекологічний університет, м. Житомир, Украӥна

На основі проведеного нами аналізу літературних джерел, результатів моніторингових та власних досліджень з'ясовано, ияо вірусні ентерити займають провідне місце в інфекиійній патологї собак $і$ наносять значні збитки власникам тварин. Вірусні ентерити призводять до тяжких розладів илунково-кишкової, серчево-судинної та дихальної систем. Доведено, ияо вони є однією з найбільш поширених причин інфекційної діареї у собак віком до 6 місяиів. Причому собачий парвовірус класифікують як основний патоген. У статті наведено результати вивчення гістологічних змін в товстому відділі кишечнику, а саме в сліпій і ободовій 
кишиі собак за експериментального зараження парвовірусним ентеритом. Проведено гістологічне дослідження товстого відділу кишечника, відібраного від трупів ( $n=5)$ иуценят, метис лабродора з безпородною, щзо були заражені польовим ізолятом парвовірусу культивованим на гетерологічних культурах клітин (СПЕВ, ВНК-21, RK-13). Присутність парвовірусу без інших асоціантів у дослідних тварин підтверджена у IФА та ІХА. Виготовлені гістологічні зрізи фарбували гематоксиліном й еозином за стандартними прописами. Загальну гістологічну будову і мікроструктурні зміни в гістологічних препаратах вивчали під світловим мікроскопом. Досліджували товстий відділ кишечнику, сліпу і ободову кишки. Гістологічним дослідженням були підтверджені й доповнені патологоанатомічні діагнози, встановлені після розтинів трупів загиблих тварин. При проведенні гістологічних досліджень сліпої й ободової кишок встановлено, щуо мікроскопічні зміни їх стінок були сегментарними. На одних ділянках крипти були добре збережені. Реєструвалися лише нерівномірний набряк підслизової основи, розиирення ї̈ кровоносних судин, а також набухання $i$ частковий лізис пучків колагенових волокон. На інших ділянках реєструвалось руйнування крипт. В частині випадків руйнувалась тільки верхня частина крипт. Строма крипт при иььому була дезорганізована й набрякла, а в ядрах досить великої кількості епітеліальних клітин у верхніх ділянках крипт реєструвались еозинофільні тільця-включення.

Ключові слова: парвовірусний ентерит собак, патолого-анатомічний розтин, гістологічні зміни, товстий відділ кишечнику, сліпа кишка, ободова кишка.

\section{Вступ}

Вірусні захворювання домашніх собак у міських умовах надзвичайно поширені, нерідко вони призводять до загибелі тварин. У собак з усіх зареєстрованих вірусних захворювань частіше зустрічаються хвороби шлунково-кишкового тракту: вірусні ентерити (парво, корона- та ротавірусний) - 43,1\%. Випадки ентеритів вірусної етіології трапляються надзвичайно часто, але їня інтенсивність дещо варіює, а саме парво$(51,6 \%)$, корона- $(18,5 \%)$ та ротавірусний ентерит (23,5\%) (Park et al., 2012; Lisova and Radzykhovskyi, 2018).

Парвовірусний ентерит - надзвичайно контагіозне інфекційне захворювання $з$ ознаками гастроентериту та міокардиту, що має високу летальність, в деяких випадках до 100\% (Lund et al., 1999; Radzykhovskyi and Zaika, 2017).

Патоморфологічні зміни при парвовірусній інфекції собак вивчені досить поверхнево, особливо враховуючи полігамність патологічних змін. Сучасна ситуація щодо розповсюдження захворюваності на парвовірусний ентерит собак потребує інтенсифікації наукових досліджень у напрямі удосконалення діагностики останнього (Lund et al., 1999; Allison et al., 2014).

Методи патоморфологічної діагностики є простими, дешевими та доступними будь-якому лікарю ветеринарної медицини. Саме $з$ них починається встановлення причини загибелі тварини, при багатьох хворобах і патологічних станах ці методи залишаються вирішальними при постановці діагнозу (Iesina and Pototskyi, 2007).

Метою даної роботи було вивчити і охарактеризувати мікроскопічні зміни в товстій кишці за експериментального зараження собак парвовірусним ентеритом.

\section{Матеріал і методи досліджень}

Розтин тварин проводили в прозекторії кафедри анатомії і гістології факультету ветеринарної медицини ЖНАЕУ. Матеріалом дослідження слугував патологічний матеріал, відібраний під час патологоанатомічного розтину від цуценят $(\mathrm{n}=5)$, після експериментального зараження і евтаназії.

Досліджували товстий відділ кишечника, сліпу і ободову кишки.
Основним методом, яким користувались в роботі, було гістологічне дослідження та опис мікроструктурних змін в тканинах органів. Патологічний матеріал після відбору одразу фіксували в $10 \%$ водному розчині нейтрального формаліну з подальшою заливкою в ущільнююче середовище (парафін). Виготовлені гістологічні зрізи фарбували гематоксиліном Караці й еозином за стандартними прописами. Загальну гістологічну будову і мікроструктурні зміни в гістологічних препаратах вивчали під світловим мікроскопом MC 100LED (Micros Austria) при збільшеннях від 70 до 1000 разів. Мікрофотографування гістологічних препаратів здійснювали за допомогою відеокамери CAM V200, вмонтованої у мікроскоп Micros MC 50 (Horalskyi et al., 2011).

Для проведення біопроби використовували 13 цуценят 45-денного віку, які були розділені на три групи: тварин першої групи (5 тварин) заражали культуральним парвовірусом, другої (5 тварин) культуральним коронавірусом, третя група (3 тварини) була контрольної - на виявлення спонтанного виникнення хвороби, на випадок інфікування до початку експерименту. Евтаназію проводили активну, використовуючи лікарські засоби, що забезпечують швидке безболісне настання смерті відповідно до Європейської Конвенцієї із захисту хребетних тварин, що використовуються для експериментальних та інших наукових цілей (Stekol'nikov and Korobov, 2004).

\section{Результати та їх обговорення}

В експерименті було використано 13 цуценят метис лабрадора 3 безпородною. На момент початку роботи тварини були в задовільному стані без будьяких ознак захворювання чи патології.

Для виключення впливу на дослід паразитарного агента на 21 та 34 день від народження собак проводили дегельмінтизацію за допомогою антигельмінтика Пірантел.

В 45-денному віці цуценят вагою 2 кг відлучили від суки і розділили на три групи, першу заражали культуральним коронавірусом, другу - культуральним парвовірусом, третя була контрольною - для виявлення спонтанного виникнення хвороби на випадок інфікування до початку експерименту.

Для зараження використовували виділений та підтверджений в ПЛР польовий парвовірус, отриманий від загиблої собаки. Інфікований біологічний матеріал 
культивували на гетерологічних культурах клітин, а саме перещеплювальні лінії культур клітин СПЕВ (нирки ембріона свині), ВНК-21 (нирки сирійського хом'яка), RK-13 (нирки кроля). В експерименті використовували культуральний вірусний ізолят, що мав 90-100\% прояв ЦПД впродовж 10 діб. Вірусовмісний культуральний ізолят заморожували при мінус $24{ }^{\circ} \mathrm{C}$. Перед використанням розморожували при кімнатній температурі і час від часу різкими рухами, матрас 3 культуральною рідиною, струшували для покращення лопання клітин та виходу віруса.

Інфікували дослідних тварин per os один раз на добу в дозі 5 мл/кг.

Перші загальні симптоми спостерігали на 4 день, а початок специфічних клінічних ознак виявляли на 6 день. У цей день провели діагностику IXА використовуючи тест системи VetExpert на наявність антигену. Отримавши позитивний результат, провели активну евтаназію, використовуючи внутрішньовенне введення Тіопенату (діюча речовина - тіопентал натрію), що забезпечує швидке безболісне настання смерті відповідно до Європейської Конвенції із захисту хребетних тварин, що використовуються для експериментальних та інших наукових цілей (Страсбург, 1986).

При проведенні гістологічних досліджень сліпої й ободової кишок встановлено, що мікроскопічні зміни їх стінок були сегментарними. На одних ділянках крипти були добре збережені. Реєструвалися лише помірний нерівномірний набряк підслизової основи, розширення її кровоносних судин, а також набухання i частковий лізис пучків колагенових волокон.

На інших ділянках реєструвалось руйнування крипт. В деяких випадках руйнувалась тільки верхня частина крипт. Строма крипт при цьому була дезорганізована й набрякла, а в ядрах досить великої кількості епітеліальних клітин у верхніх ділянках крипт реєструвались еозинофільні тільця-включення.

У ділянці дна крипт сліпої й ободової кишок на ділянках $з$ руйнуванням верхньої частини крипт велика кількість епітеліальних клітин містила внутрішньоядерні еозинофільні тільця-включення. Частина таких ядер були деформованими. Зазвичай клітини з внутрішньоядерними тільцями-включеннями перебували в стані зернистої дистрофії. Частина таких клітин руйнувалась. Також тут реєструвався субепітеліальний набряк, який був набагато сильнішим, ніж у середній та у верхній частинах крипт.

Наявність еозинофільних тілець-включень в ядрах епітелію крипт є гістологічним підтвердженням розмноження в цих клітинах парвовіруса (Cheville, 1975; Orljankin, 1986).

Епітеліоцити, в ядрах яких не виявлялись еозинофільні тільця-включення перебували в стані зернистої та гідропічної дистрофій. Частина з дистрофічно змінених клітин, у ядрах яких еозинофільні тільцявключення були відсутні, також руйнувалась.

При руйнуванні значної частини ентероцитів крипт незруйновані епітеліальні клітини витягувалися вздовж базальної мембрани, набуваючи пласкої форми.

У просвіті крипт, у яких руйнувалась значна кількість ентероцитів, виявлялась велика кількість клі- тинного детриту, злущені епітеліальні клітини як 3 еозинофільними тільцями-включеннями в їхніх ядрах, так і без них, а також епітеліоцити 3 повністю еозинофільними ядрами.

У частині крипт сліпої й ободової кишок в їх нижній ділянці реєструвалась виразна гіперплазія келихоподібних клітин. Епітелій у цих ділянках був представлений головним чином келихоподібними клітинами, між якими виявлялись лише поодинокі чи невеликі групки ентероцитів.

Руйнування епітелію крипт, його базальної мембрани та виразний набряк слизової оболонки в ділянці крипт на частині ділянок сліпої й ободової кишок призводив до повної дезорганізації цієї оболонки. Особливо виразним порушення структури слизової оболонки було в ділянці скупчених лімфоїдних вузликів.

У м'язовій пластинці слизової оболонки встановлена зерниста дистрофія її гладких м'язових клітин.

Підслизова основа була набрякла, нерівномірно інфільтрована лімфоцитами та поодинокими моноцитами й макрофагами. Поодинокі й скупчені лімфоїдні вузлики були помітно збільшені в розмірі. В ядрах багатьох лімфоцитів, які їх утворювали, виявлялись еозинофільні тільця-включення, а подекуди спостерігались вогнища некрозу лімфоцитів.

У м'язовій оболонці реєструвалась зерниста дистрофія внутрішнього й зовнішнього шарів іiі м'язової оболонки. Частина дистрофічно змінених клітин руйнувалась.

Серозна оболонка мікроскопічних змін не мала або ж була виразно потовщена внаслідок іiі набряку.

У прямій кишці мікроскопічні зміни були відсутні за винятком помірного набряку підслизової основи та розширення й переповнення кров'ю іiі кровоносних судин.

\section{Висновки}

1. У товстій кишці цуценят за експериментального зараження ізолятом парвовіруса, культивованим у гетерологічній культурі клітин, ураження локалізуються в сліпій і ободовій кишках і мають сегментарний характер: на одних ділянках крипти добре збережені, а на інших реєструється руйнування крипт.

2. Місцева реакція системи специфічного імунітету характеризується гіпертрофією поодиноких і скупчених лімфоїдних вузликів. Місцями виявляються невеликі осередки некрозу лімфоцитів.

3. В ядрах епітеліоцитів крипт, а також у ядрах лімфоцитів виявляються еозинофільні тільцявключення.

Перспективи подальших досліджень. На наступному етапі дослідження доцільним є порівняння патоморфологічних особливостей експериментально відтвореного парвовірусу природною інфекцією у собак.

\section{References}

Horalskyi, L.P., Khomych, V.T., \& Kononskyi, O.I. (2011). Osnovy histolohichnoi tekhniky i 
morfofunktsionalni metody doslidzhen u normi ta pry patolohii. Navchalnyi posibnyk. Zhytomyr: "Polissia" (in Ukrainian).

Lisova, V.V., \& Radzykhovskyi, M.L. (2018). Patomorfolohichna diahnostyka enterytiv virusnoi etiolohii v sobak. Nauk. Visn. LNUVM ta BT im. S.Z. Hzhytskoho, 20(83), 299-303. doi: 10.15421/nvlvet8360 (in Ukrainian).

Iesina, E., \& Pototskyi, M. (2007). Znachennia patomorfolohichnykh doslidzhen u diahnostychnykh doslidzhenniakh tvaryn. Veterynarna medytsyna Ukrainy, 3, 27-29 (in Ukrainian).

Orljankin, B.G. (1986). Parvovirusy zhivotnyh. C-h. biologija, 11, 23-34 (in Russian).

Radzykhovskyi, M.L., \& Zaika, S.S. (2017). Patomorfolohichna kharakterystyka parvovirusnoho enterytu $\mathrm{v}$ sobak. Nauk. Visn. LNUVM ta BT im. S.Z. Hzhytskoho, 19(82), 45-49. doi:10.15421/nvlvet8210 (in Ukrainian).

Stekol'nikov, A.A., \& Korobov, A.V. (2004). Professional'naja jetika vracha veterinarnoj mediciny. Spb.: Lan' (in Russian).
Allison, A.B. Kohler D.J., Ortega A. et al. (2014). Hostspecific parvovirus evolution in nature is recapitulated by in vitro adaptation to different carnivore species. PLoS. Pathog., 11, 6-10. doi: 10.1371/journal.ppat.1004475.

Cheville, N.F. (1975). Cytopathology in viral diseases. Monogr. Virol., 10(1), 1-99. https://www.ncbi.nlm. nih.gov/pubmed/172783.

Lund, E.M., Armstrong, P.J., Kirk, C.A., Kolar, L.M., \& Klausner, J.S. (1999). Health status and population characteristics of dogs and cats examined at private veterinary prac-tices in the United States. Journal of the American Veterinary Medical Association, 214, 1336-1341. https://www.ncbi.nlm.nih.gov/pubmed/ 10319174.

Kumar, M., Nandi, S., \& Chidri, S. (2010). Development of a polyclonal antibody - based AC - ELISA and its comparision with PCR for dignosis of canine parvovirus infection. Berlin Hedelberg, virologica sinica, 25(5), 352-360. doi: 10.1007/s12250-010-3132-x.

Park, S.A., Park, S.Y., \& Song, C.S. (2012). Development of a novel vaccine against canine parvovirus infection with a clinical isolate of the type $2 \mathrm{~b}$ strain. Clin Exp Vaccine Res, 1(1), 70-76. doi: 10.7774/cevr.2012.1.1.70. 